\title{
AUDIT INTERNAL LEMBAGA KEUANGAN SYARIAH DALAM PERPEKTIF AL-HISBAH
}

\author{
Ahmad Baehaqi \\ ${ }^{1}$ STEI SEBI Depok \\ baehaqi17@gmail.com \\ Suyanto \\ Universitas Muhammadiyah Jakarta \\ yantoppa@yahoo.com
}

\begin{abstract}
Audit Internal Lembaga Keuangan Syariah (LKS) harus memiliki cakupan lebih luas dibandingkan audit konvensional, mengingat LKS memiliki keharusan untuk mematuhi prinsip syariah (sharia compliance). Dalam Islam, institusi al-Hisbah dan muhtasib telah berperan untuk menjaga kegiatan ekonomi masyarakat agar berjalan sesuai dengan tuntunan syariah. Penelitian ini bertujuan untuk mengeksplorasi peranan audit internal LKS dalam perspektif al-Hisbah, untuk menjaga kesesuaian operasional LKS tergadap prinsip syariah. Hasil penelitian menunjukkan bahwa audit internal LKS belum didukung oleh kompetensi syariah yang memadai dan panduan pemeriksaan berkaitan dengan aspek syariah. Audit internal harus berperan membantu Dewan Pengawas Syariah (DPS) dalam melakukan proses pemeriksaan aspek pemenuhan syariah.
\end{abstract}

Kata Kunci: Audit Internal, Sharia Compliance, LKS, al-Hisbah

\section{PENDAHULUAN}

Tiga dekade terakhir ini telah banyak bermunculan lembaga-lembaga berlebel Islam seperti lembaga amil zakat, lembaga wakaf, perbankan syariah, lembaga pembiayaan syariah, asuransi syariah, lembaga keuangan mikro syariah seperti baitul mal watamwil (BMT) dan koperasi syariah. Era globalisasi yang dialami dunia saat ini berdampak langsung pada aktivitas ekonomi serta memberikan tantangan besar bagi pelaksanaan sistem keuangan Islam sebagai solusi sistem konvensional. Motivasi ini telah menyebabkan munculnya Lembaga Keuangan Syariah (LKS) tidak hanya dalam negara yang mayoritas berpenduduk Islam, tetapi juga di negaranegara Barat.

Perkembangan

terbaru

memperlihatkan Lembaga Keuangan Syariah (LKS) berkompetisi untuk mengeluarkan produk dan layanan kepada nasabah. Namun, bias jadi LKS mengabaikan aspek syariah tertentu yang akhirnya mempengaruhi sifat kepatuhan syariah (shariah compliance) yang menjadi elemen utama yang harus dipelihara. Hal demikian terjadi karena bank-bank dengan lebel syariah tidak selalu diikuti dengan pengelolaan usaha yang benar-benar sesuai prinsip syariah, tetapi sebagian didirikan hanya demi kepentingan bisnis semata (Thayibatun, 2009).

Lembaga Keuangan Syariah (LKS) memiliki karakteristik yang berbeda dengan Lembaga Keuangan Konvensional (LKK). LKS diharuskan untuk mematuhi segala ketentuan syariah (sharia compliance) dalam menjalankan kegiatan usaha dan produknya. Perbedaan karakteristik ini mempengaruhi bentuk dan standard pengawasan dan audit terhadap LKS. Kebutuhan atas kepastian pemenuhan syariah ini mendorong munculnya fungsi 
audit baru, yaitu audit syariah. Dalam hal ini, auditor syariah memegang peran krusial untuk memastikan akuntabilitas laporan keuangan dan pemenuhan aspek syariah. Sehingga stakeholder merasa aman berinvestasi dan dana yang dimiliki oleh LKS dapat dipastikan telah dikelola dengan baik dan benar sesuai dengan syariat Islam (Mardiyah dan Mardiyan, 2015).

Tidak seperti audit keuangan konvensional yang mengharuskan auditor untuk mengungkapkan pandangan mereka bahwa laporan keuangan disusun sesuai dengan GAAP dan standar pelaporan keuangan yang relevan, audit Lembaga Keuangan Syariah (LKS) mencakup berbagai lingkup. Hal ini membuktikan bahwa manajemen telah memenuhi tidak hanya dengan standar yang relevan tetapi juga kerangka syariah dalam semua transaksi untuk mencapai maqasid syariah (Yacoob, et.al., 2012). Menurut Haniffa (2010) ini penting untuk melindungi dan memperbaiki kondisi kehidupan manusia dalam semua dimensi.

Dengan kata lain, audit lembaga keuangan Islam tidak hanya terbatas pada audit keuangan, tetapi harus mencakup tinjauan syariah. Namun Audit yang ada saat ini merupakan bagian dari sistem keuangan konvensional yang lebih menilai aspek ekonomi saja. Dalam sejarah Islam, semasa zaman Nabi Muhammad SAW dan sepanjang pemerintahan Khalifah yang empat, lembaga al-Hisbah dan peranan Muhtasib telah memainkan peranan yang sangat penting. Fungsi al-Hisbah atau audit dalam LKS sangat penting karena mencerminkan akuntanbilitas LKS bukan saja kepada stakeholder, tetapi lebih penting lagi kepada Sang Pencipta (Allah swt). Ini adalah karena umat Islam percaya bahwa tindakan dan pemikiran seseorang itu selalu diawasi oleh Allah (muraqabah). Firman Allah swt: "... sungguh, Allah memperhitungkan segala sesuatu" (Surah an-Nisa': 86).
Kepentingan lembaga al-Hisbah tidak dapat dinafikan kerana ia berperan untuk memastikan kebenaran dan keterbukaan (transparansi) sesuatu urusan muamalat dilaksanakan dan ditegakkan dalam perspektif syariah. Sebagaimana firman Allah SWT: “... Sesungguhnya Allah selalu menjaga dan mengawasimu." (Surah an-Nisa': 1). Berdasarkan uraian diatas, penelitian ini bertuuan untuk (i) melihat dinamisme konsep audit syariah dalam sistem keuangan Islam, (ii) menegaskan pandangan Islam terhadap pengamalan dan pengaplikasian konsep al-Hisbah dalam audit Syariah, dan mengoptimalkan peran audit internal LKS dalam kerangka alHisbah.

\section{KERANGKA TEORITIS DAN HIPOTESIS}

\section{Audit Internal}

Menurut Agoes (2012), internal audit adalah audit yang dilakukan oleh bagian auditor internal perusahaan, baik terhadap laporan keuangan dan catatan akuntansi perusahaan, maupun ketaatan terhadap kebijakan manajemen puncak yang telah ditentukan dan ketaatan terhadap peraturan pemerintah dan ketentuanketentuan dari ikatan profesi yang berlaku. Peraturan pemerintah yang dimaksud adalah peraturan di bidang perpajakan, pasar modal, lingkungan hidup, perbankan, perindustrian, investasi dan lain-lain. Sedangkan ketentuan-ketentuan dari ikatan profesi yaitu Pernyataan Standar Akuntansi Keuangan. Terdapat beberapa hal penting dari pengertian diatas, yaitu:

a. Objek yang diperiksa adalah laporan keuangan yang telah disusun oleh manajemen beserta catatan-catatan pembukuan dan bukti-bukti pendukungnya,

b. Dasar pemeriksaan adalah kesesuaian dengan kebijakan manajemen, ketentuan hukum positif dan standar akuntansi, dan 
c. Pemeriksaan dilakukan secara kritis dan sistematis melalui proses perencanaan sebelum audit dilakukan.

Ruang lingkup dan tugas audit internal tergantung pada permintaan dari manajemen organisasi. Kegiatan audit internal secara umum meliputi kegiatan mereview akuntansi dan sistem pengendalian internal, pemeriksaan pengelolaan informasi keuangan dan perusahaan yang beroperasi dan pemeriksaan apakah kegiatan ekonomi perusahaan termasuk kontrol non-keuangan organisasi. Keberadaan audit internal, diperlukan untuk mendukung tanggung jawab komite audit (Rini \& Fitri, 2015).

\section{Lembaga Keuangan Syariah (LKS)}

Lembaga Keuangan Syariah (LKS) adalah lembaga keuangan yang menjalankan usahanya berdasarkan kepada prinsip syariah. Tujuan utama pendirian LKS sebagai lembaga keuangan yang didasarkan pada prinsip syariah adalah agar kaum muslimin terhindar dari lembaga keuangan (LK) konvensional yang menggunakan sistem bunga (riba) yang diharamkan oleh syariah. Selain itu, LK konvensional juga tidak mempertimbangkan aspek kehalalan dalam investasi baik objek ataupun caranya. (Antonio, 2001).

LKS menjalankan usahanya, bergantung pada dana dan kepercayaan masyarakat. Pelaksanaan Good Corporate Governance (GCG) diperlukan untuk membangun dan meningkatkan kepercayaan masyarakat terhadap LKS. Perangkat mekanisme jaminan kepatuhan syariah melalui peran DPS merupakan perangkat yang membedakan antara GCG pada LKS dengan LK konvensional. Hal ini dikarenakan LKS memiliki kewajiban untuk memenuhi prinsip syariah dalam kegiatan usahanya.

Chapra dan Ahmed menggambarkan peran kunci dalam struktur GCG LKS. Selain struktur normal GCG sebagaimana yang terdapat pada LK konvensional, seperti direksi, audit internal dan lainnya, pada LKS juga terdapat DPS. Kegiatan LKS harus senantiasa sesuai dengan prinsip syariah. Selain itu, Chapra dan Ahmed (2002) juga menjelaskan peran penting audit internal membantu DPS untuk memastikan kepatuhan LKS terhadap prinsip syariah.

\section{Al-Hisbah}

Al-Hisbah berarti lembaga negara yang bertugas menyuruh melakukan kebaikan dan mencegah apa yang buruk (al-amr bi al-ma'ruf wa al-nahyu 'an almunkar) (Khan, 2016; al-Mawardi dalam Halim, 2011). Selanjutnya, menurut Mubarak (dalam Halim, 2011), al-hisbah adalah pengawasan administrasi yang dilaksanakan oleh pemerintah dengan menugaskan pejabat khusus untuk mengawasi masalah akhlak, agama, ekonomi, tepatnya dalam lapangan sosial secara umum dalam rangka mewujudkan keadilan dan keutamaan yang sesuai dengan prinsip-prinsip yang terdapat dalam syariat Islam.

Al-Hisbah merupakan lembaga pemerintah yang dalam pelaksanaannya didelegasikan kepada seseorang yang disebut muhtasib. Muhtasib bertugas mengawal seluruh aktivitas ekonomi, keagamaan, kesehatan dan urusan kota serta administrasi sebuah kota. Selanjutnya, muhtasib memastikan segala aktivitas tersebut tidak bertentangan dengan hukum syariah dan menghukum mereka yang bersalah. Ini dilakukan dalam kerangka amar ma'ruf nahi munkar. Allah SWT telah mengabarkan agar setiap muslim memainkan suatu peran aktif dalam amar ma'ruf nahi munkar. Hal ini telah dijadikan sebagai fardlu kifayah (kewajiban kolektif), suatu kewajiban yang harus tetap ditunaikan oleh sebagian orang di masyarakat. Sebagaimana dalam firman Allah:

Artinya: "Dan hendaklah ada diantara kalian segolongan umat yang menyeru 
kepada kebajikan, menyuruh kepada yang ma'ruf dan mencegah dari yangmunkar. Merekalah orang-orang yang beruntung" (QS Ali Imran : 104).

Amar ma'ruf nahi munkar adalah merupakan fardlu kifayah yang dapat menjadi fardlu 'ain bagi mereka yang berkemampuan ketika belum ada yang menunaikannya. Kemampuan yang dimaksud adalah kekuatan dan kekuasaan. Jadi mereka yang memiliki kekuatan (kekuasaan) lebih mampu daripada yang lain. Mereka inilah yang berkewajiban, bukan orang lain. Sebab, timbulnya kewajiban adalah berdasar kemampuan (alqudrah), dan orang wajib berbuat sesuai dengan kemampuannya. Seluruh kekuasaan Islam tujuannya adalah amar ma'ruf dan nahi munkar (Ibnu Taimiyah, edisi terjemahan 2016).

Umat Islam telah diperintahkan agar melembagakan pengawasan penerapan kewajiban amar ma'ruf nahi munkar ini "menyuruh berbuat yang ma'ruf dan mencegah dari perbuatan mungkar" (Surah al-Hajj 22: 41). Muhtasib yang menjalankan institusi hisbah, dalam menjalankan tugas memiliki standar utama yang menonjol, yaitu: Pertama, muhtasib bertanggung jawab untuk memastikan bahwa seluruh masyarakat memiliki organisasi dan fasilitas yang memadai untuk beribadah. Demikian pula ia akan menolak setiap pengabaian dan ketidaktaatan atas kewajiban-kewajiban syariah lain. Kedua, muhtasib memantau penegakan keadilan di masyarakat. Ia berusaha untuk menegakkan fair play dalam berbagai sektor ekonomi guna meminimalisir eksploitasi yang mungkin terjadi. Wilayah tugas muhtasib ini yang perlu disesuaikan dengan pola-pola produksi, distribusi, dan pertukaran sekarang. Ketiga, muhtasib memberikan perhatian yang khusus terhadap berbagai layanan umum khususnya kondisi kesehatan kota (Khan, 2016).

\section{METODE PENELITIAN}

Metode yang digunakan dalam penelitian ini adalah metode kualitatif dengan pendekatan deskriptif. Penelitian kualitatif berlandaskan pada paham nonpositivisme dengan menekankan hasil penelitian pada makna (Aman, 2007). Penelitian kualitatif menggunakan data-data kualitatif, tidak berupa angka, yang dapat dikumpulkan melalui observasi, wawancara, telaah dokumen dan sebagainya (Suryana, 2007). Sedangkan penelitian deskriptif dilakukan untuk mengetahui variabel mandiri, tanpa membuat perbandingan atau menghubungkan dengan variabel yang lain (Sugiyono, 2009).

Paradigma yang digunakan dalam penelitian ini adalah paradigma tauhid, bukan paradignnnnma interpretif seperti penelitian yang menekankan pada makna umumnya. Paradigma interpretif tidak memiliki asumsi fundamental tentang Tuhan dalam ilmu pengetahuan (Kamayanti, 2016), sehingga tidak tepat digunakan sebagai paradigma penelitian akuntansi syariah. Selain itu, paradigma interpretif hanya berdasarkan pada kebenaran empiris semata untuk mendapatkan ilmu pengetahuan, belum dipandu dengan kebenaran ilahiyah (Kamayanti, 2016). Sekalipun penelitian ini menekankan hasil penelitian pada makna, tetapi makna tersebut dipandu dengan kebenaran ilahiyah dari Al-Qur'an dan sunnah sebagai sumber utama ilmu pengetahuan dalam Islam.

Unit analisis dalam penelitian ini adalah dokumen atau teks tertulis berkaitan dengan masalah penelitian, yaitu menganalisis peranan audit internal pada Lembaga Keuangan Syariah dalam perspektif al-Hisbah. Data penelitian berupa data sekunder, baik berasal dari sumber (penulis) pertama atau sumber (penulis) kedua, terdiri dari berbagai literatur, buku teks akademik, karya ilmiah dan hasil penelitian, peraturan dan undang-undang serta informasi lain berkaitan dengan 
masalah penelitian. Data-data tersebut dikumpulkan melalui proses telaah dokumen atau kajian kepustakaan (library research).

Data yang telah terkumpul, selanjutnya dianalisis dengan menggunakan analaisis isi kualitatif (qualitative content analysis) atau disebut juga analisis isi deskriptif (descriptive content analysis) karena bertujuan untuk menggambarkan (descript) secara detail isi (content) (Eriyanto, 2011) dari berbagai dokumen tertulis yang mengkaji permasalahan berkaitan dengan peranan audit internal dan kepatuhan syariah (sharia compliance) dari Lembaga Keuangan Syariah (LKS) dalam perspektif al-Hisbah.

\section{HASIL DAN PEMBAHASAN}

\section{Audit Internal LKS}

Pada umumnya dalam LKS, kita mengenal ada dua cara yang melakukan audit yaitu audit internal, dan auditor eksternal. Audit internal meliputi pemeriksaan dan evaluasi kecukupan dan efektivitas sistem pengendalian internal organisasi dan kualitas kinerja dalam melaksanakan tanggung jawab yang ditugaskan (Imran, et.al., 2012). Auditor internal harus melaksanakan:

a. Merreview keandalan (realibilitas dan integritas) informasi finansial dan operasional serta cara yang digunakan untuk mengidentifikasi, mengukur, mengklasifikasi dan melaporkan informasi tersebut.

b. Merreview berbagai sistem yang telah ditetapkan untuk memastikan kesesuaiannya dengan berbagai kebijakan, rencana, prosedur, hukum dan peraturan yang dapat berakibat penting terhadap kegiatan organisasi, serta menentukan apakah organisasi telah mencapai kesesuian. c. Mereview berbagai cara yang dipergunakan untuk melindungi harta dan bila dipandang perlu, memverifikasi keberadaan harta-harta tersebut.

d. Menilai keekonomisan dan keefisienan penggunaan berbagai sumber daya.

e. Mereview berbagai operasi atau program untuk menilai apakah hasilnya akan konsisten sesuai dengan yang diwacanakan.

Menurut kajian Baehaqi (2014: 127), audit internal LKS (bank syariah) masih belum didukung dengan orang yang kompeten dalam bidang operasional LKS (bank syariah), khususnya berkaitan dengan prinsip syariah, sehingga tidak memiliki kompetensi untuk melakukan audit terkait aspek syariah (internal sharia review). Selain itu, audit internal juga tidak memiliki panduan khusus dari DPS ketika melakukan review berkaitan dengan aspek syariah apa saja yang harus diperhatikan.

\section{Audit Syariah}

Audit LKS dapat didefinisikan sebagai proses sistematis untuk mendapatkan dan mengevaluasi bukti obyektif mengenai asersi tentang tindakan dan peristiwa keagamaan dan sosial ekonomi, dalam rangka untuk memastikan tingkat keterkaitan antara pernyataan dan kerangka pelaporan keuangan yang berlaku, termasuk kriteria yang ditentukan berdasarkan prinsip-prinsip syariah seperti yang direkomendasikan oleh Dewan Pengawas Syariah (DPS), dan mengkomunikasikan hasilnya kepada semua pihak yang berkepentingan (Haniffa, 2010). Sementara itu, Hameed (2008) mendefinisikan audit syariah sebagai proses sistematis mendapatkan dan mengevaluasi bukti obyektif mengenai asersi tentang tindakan dan peristiwa sosial ekonomi, agama dan lingkungan dalam rangka untuk memastikan tingkat korespondensi antara 
pernyataan dan syariat (hukum Islam), dan mengkomunikasikan hasilnya kepada pengguna. Dalam definisi Haniffa Hameed terdapat unsur sosial ekonomi, agama (prinsip syariah) dan lingkungan sebagai ruang lingkup dari audit syariah.

Dari sudut operasional, AAOIFI melalui Governance Standards for Islamic Financial Institutions (GSIFIs) No. 2 mendefinisikan Audit Syariah adalah pemeriksaan suatu kepatuhan LKS terhadap Syariah, dalam semua kegiatan, khususnya laporan keuangan dan komponen operasional lainnya dari LKS, yang terkena risiko kepatuhan termasuk namun tidak terbatas pada produk, teknologi yang mendukung operasi, proses operasional, orang-orang yang terlibat dalam bidang utama risiko, dokumentasi dan kontrak, kebijakan dan prosedur dan kegiatan lain yang membutuhkan kepatuhan terhadap prinsip-prinsip Syariah (Yacoob: 2013 dan Mohiuddin: 2012).

Definisi AAOIFI menggambarkan proses yang sangat komprehensif dan lengkap untuk memastikan pemenuhan kepatuhan LKS terhadap syariah dalam segala aktivitasnya. Audit meliputi kontrak, perjanjian, kebijakan, produk, transaksi, memorandum dan anggaran dasar, laporan keuangan, laporan (audit terutama internal dan pemeriksaan bank sentral), surat edaran, dan lain-lain. Audit syariah harus memastikan bahwa LKS memiliki sistem pengendalian intern yang baik dan efektif untuk mematuhi syariat Islam. (ISRA, 2015 dan Yacoob, 2012).

\section{Internal Sharia Review (Audit Syariah) Berasaskan al-Hisbah}

Bagian ini menghubungkan internal sharia review atau audit syariah yang dilakukan oleh audit internal dengan lembaga al-Hisbah. Al-Hisbah adalah salah satu lembaga ekonomi yang paling awal dalam Islam yang pelaksanaannya dilakukan oleh muhtasib (pengawas/pemeriksa).
Auditor atau audit internal bertindak sebagai muhtasib, yaitu unit kerja yang memperoleh kewenangan dari manajemen LKS (Pemegang Saham) dalam melakukan porses pemeriksaan internal terhadap aspek syariah. Audit internal (muhtasib) mengawal seluruh aktivitas/kegiatan LKS, dilakukan dengan tata kelola perusahaan yang sesuai dengan syariah Islam dalam kerangka amar ma'ruf dan nahi munkar. Audit internal bertanggungjawab tidak hanya kepada manajemen (pemegang saham) selaku pemberi kewenangan, namun juga bertanggung jawab kepada Allah SWT.

Tanggung jawab utama muhtasib adalah untuk memastikan bahwa praktek bisnis yang terjadi di pasar sesuai dengan ajaran-ajaran Islam dan masing-masing pihak mendapatkan haknya dan menjalankan kewajibannya. Auditor kurang lebih memiliki tugas yang sama seperti yang dilakukan oleh muhtasib dahulu, meskipun peran auditor internal dibatasi hanya pada pemeriksaan yang mengacu kepada peraturan, sedangkan muhtasib berkonsentrasi pada pemeriksaan fisik pasar (Lahsasna, et.al., $\mathrm{tt}$ ).

Audit internal memegang peran dan tanggung jawab yang sangat penting dalam LKS. Audit internal tidah hanya harus memastikan LKS menjalankan bisnis sebagaimana lembaga keuangan yang lain, namun juga harus memastikan LKS mematuhi prinsip dan aturan syariah dalam operasinya. Auditor syariah internal mempunyai peran kunci, karena ada kesadaran yang semakin besar diantara LKS dan stakholder-nya bahwa setiap LKS harus membantu mencapai tujuan-tujuan hukum Islam (maqashid syariah) yaitu kemaslahatan umat manusia. Dengan melihat tugas dan tanggung jawab, audit syariah internal dapat dikatakan audit internal berperan sebagai muhtasib dalam kerangka al-Hisbah dalam lingkup LKS. Institusi audit syariah internal, dalam menjalankan tugas menghadapi banyak tantangan, yaitu: ruang lingkup audit, bukti 
audit, kualifikasi auditor dan independensi auditor.

\section{Ruang Lingkup Audit Syariah}

Dalam audit konvensional, ruang lingkup audit jelas dinyatakan sebagai menjadi pedoman bagi auditor untuk bersikap objektif dalam pengumpulan bukti mereka. Jika tidak, penugasan audit akan menjadi lebih lama dan sumber daya seperti waktu dan uang yang terbuang karena tidak ada ruang lingkup yang jelas untuk pekerjaan audit. Audit syariah diklaim sebagai fungsi sosial; Oleh karena itu, ruang lingkup harus lebih luas meliputi perilaku sosial dan kinerja organisasi termasuk hubungan mereka dengan semua pemangku kepentingan (Yaccob, et.al., 2012).

LKS saat ini belum sepenuhnya ditangani secara sistematis dalam pelaksanaan audit syariah, yaitu tidak ada tinjauan sistematis secara komprehensif telah dilakukan untuk memastikan kepatuhan syariah yang tepat. Oleh karena itu, audit syariah harus melibatkan review sistematis dari aspek operasional dari lembaga keuangan Islam. Ini termasuk audit kebijakan dan prosedur dari lembaga keuangan Islam, seperti manual produk, proses operasional dan kontrak. Hal ini juga perlu meninjau struktur organisasi untuk memastikan apakah itu layak untuk melakukan kegiatan sesuai syariah (Rahman, 2008). Tidak adanya ruang lingkup audit syariah telah meninggalkan kegelapan bagi industri. Tampaknya bahwa lembaga keuangan Islam sendiri tidak mengambil langkah yang tepat untuk memastikan pembuat standar dan badan pengawas untuk serius melihat ini. Pada saat ini, ruang lingkup yang tergantung pada penasihat syariah dan Dewan Pengawas Syariah yang mengawasi review syariah atau audit syariah (Yaccob, et.al., 2012).

Kasim et al., (2009) menyatakan bahwa, kurangnya keahlian, spesifikasi dan definisi tentang ruang lingkup praktek audit syariah menimbulkan masalah yang menyebabkan kesenjangan yang ada antara yang diinginkan dan yang sebenarnya. Selain itu, Rahman (2008) mengusulkan untuk mengembangkan program audit yang sistematis dan menyeluruh, yaitu daftar prosedur audit untuk seluruh audit syariah, termasuk dokumentasi hukum untuk prosedur operasional dan sebagainya. Ini adalah program yang desain untuk mengaudit area tertentu dari lingkup keseluruhan audit, dan dapat dikembangkan untuk menutupi berbagai produk dan jasa keuangan Islam. Program audit syariah perlu ditulis dalam bahasa yang dapat dengan mudah dipahami oleh stakeholder potensial. Masukan mereka diperlukan setelah periode pengujian program audit syariah dalam praktek yang sebenarnya.

Menurut penelitian Kasim, et al. (2009) di Malaysia, sebagian besar responden setuju bahwa kerangka audit syariah harus berbeda dari kerangka audit konvensional. Selain itu, mereka sepakat bahwa regulator LKS harus bertanggung jawab untuk merumuskan dan menerapkan kerangka audit syariah yang komprehensif dan terintegrasi dan diikuti oleh semua lembaga keuangan syariah.

Oleh karena itu, ruang lingkup audit setidaknya mencakup: a) audit atas aspek keuangan LKS meliputi (i) capital (sumber pendanaan: equity atau debt), (ii) investasi, (iii) pengelolaan dana/treasury (manajemen risiko dan mekanisme hedging), (iv) pendapatan dan beban, (v) distribusi (distribusi profit, zakat dan dana kebajikan dan non halal, b) audit kepatuhan atas seluruh organisasi, karyawan dan aplikasi sistem informasi, dan (iii) review proses tata kelola perusahaan dalam pemenuhan syariah. Audit atas pemenuhan syariah auditor perlu melakukan observasi terhadap transaksi terlarang oleh syariah (riba, gharar, mayshir dan aktivitas terlarang lainnya), pemenuhan persyaratan kontrak (akad) 
sesuai syariah, ketepatan penggunaan konsep syariah dan pemenuhan maqashid syariah.

\section{Bukti Audit}

Bukti audit didefinisikan sebagai segala informasi yang digunakan oleh auditor untuk menentukan apakah informasi teraudit tersebut sesuai dengan kriteria-kriteria yang sudah ditetapkan. Dalam lembaga keuangan konvensional, kriteria-kriteria yang digunakan biasanya adalah IFRS. Terkait proses audit syariah, kriteria-kriterianya dibatasi menurut opini tertulis dari DPS, manual-manual produk, serta prosedurprosedur operasi standar. Auditor syariah harus melibatkan diri pada peninjauan sistematis terhadap aspek-aspek operasional suatu LKS, mencakup penelaahan kebijakan-kebijakan dan prosedur-prosedur terkait masing-masing manual produk, proses dan kontrak (Kasim, et al: 2009).

\section{Kualifikasi Auditor}

Menurut Standar Audit AAOIFI (2010), auditor harus memiliki pengetahuan tentang aturan dan prinsip-prinsip syariat Islam. Namun, ia tidak akan memiliki tingkat yang sama pengetahuan sebagai yang anggota dewan pengawas syariah dan dengan demikian auditor tidak akan diharapkan untuk memberikan interpretasi aturan-aturan dan prinsip- prinsip (Islam). Fatwa, putusan dan bimbingan yang dikeluarkan oleh DPS menjadi dasar bagi auditor untuk mempertimbangkan apakah LKS telah memenuhi aturan dan prinsipprinsip syariat Islam. Auditor juga harus menggunakan ini sebagai dasar untuk menyimpulkan apakah laporan keuangan LKS telah disusun sesuai dengan aturan syariat Islam dan prinsip-prinsip (Yacoob, et all., 2012).

Bukti empiris dalam praktik terdapat kekurangan auditor yang memiliki kedua kualifikasi, yang secara tidak langsung mereka penting dalam menentukan visi dan misi Islam yang diemban oleh LKS. Auditor syariah diharapkan untuk mencerminkan tanggung jawab dan akuntabilitas mereka tidak hanya kepada manajemen dan stakeholder, tetapi yang lebih penting kepada Allah. Ini akan menjadi dasar untuk membangun kepercayaan publik dan menjamin bahwa LKS mematuhi syariah dalam semua kegiatan mereka (Kasim, et.al., 2009). Muhtasib, yang memiliki pengetahuan dalam syariah dan juga di bidang akuntansi, keuangan benar-benar meningkatkan kemandirian mereka. Mereka tidak hanya independence in appearance tetapi juga independence in fact (Uddin, et.al., 2013)

Nor Aishah, et. Al (2015) mengusulkan agar auditor syariah memiliki lebih banyak eksposur melalui program pelatihan syariah tersertifikasi, badan-badan profesional selain dari pelatihan internal yang disediakan oleh auditor syariah yang senior di masing- masing LKS. Selain itu, juga pada saat belajar di perguruan tinggi untuk mempertimbangkan menambahkan auditing syariah ditambah dengan program keuangan Islam lainnya ke dalam kurikulum untuk gelar sarjana untuk mempersiapkan lulusan menuju menjadi auditor syariah di masa depan. Auditor syariah harus menyatukan pengetahuan yang memadai, kapabilitas dan independen untuk melakukan audit. Mereka harus telah dilatih sama baiknya di bidang akuntansi dan keuangan dan audit serta syariah dan fiqh (Yaacob, 2012).

\section{Independensi Auditor}

Dalam praktek, ketergantungan yang sangat dibebankan pada auditor internal atau manajemen unit syariah untuk melaksanakan pemeriksaan syariah di lembaga keuangan Islam. Kendala review internal dapat terjadi karena tidak ada pemisahan yang jelas terhadap tugas telah ditentukan. Dengan demikian, meskipun responden yang jelas tentang apa yang sebenarnya diinginkan kemerdekaan, tetapi 
dalam fakta-fakta yang sebenarnya mereka tidak dapat menghindari untuk lepas pada prinsip independen karena keadaan tidak dapat dihindari. Hal ini menyebabkan potensi penuh dari audit tidak dapat direalisasikan jika mereka tidak sepenuhnya dan benar-benar independen, sebagai tujuan sosial (manfaat bagi umat) akan gagal (Kasim et al., 2009). Untuk itu perlu dipertimbangkan menempatkan struktur audit internal (syariah) pada posisi yang independen. Audit internal yang tidak bertanggunjawab kepada Dewan Direksi, namun bertanggung jawab kepada Komite Audit. Dalam operasional kesehariannya audit internal bekerja sama dan koordinasi dengan Dewan Pengawas Syariah.

\section{KESIMPULAN}

Konsep al-Hisbah yang telah dipraktikan pada masa Rasulullah dan Kekhalifahan memiliki persamaan dengan pelaksanaan audit LKS (audit syariah). Kedudukan al-Hisbah berdasarkan dalil daripada al-Qur'an. LKS yang semakin berkembang, membutuhkan audit syariah yang akan memastikan pemenuhan terhadap prinsip syariah (sharia compliance). Audit yang dilakukan saat ini, merupakan bagian dari sistem keuangan konvensional yanng lebih menilai pada aspek ekonomi saja. Pengembangan audit syariah oleh audit internal LKS masih belum berjalan ideal. Audit internal LKS belum didukung oleh kompetensi syariah yang memadai dan panduan pemeriksaan berkaitan dengan aspek syariah. Selain itu, dukungan peraturan juga belum mampu menunjukkan dengan jelas peran audit internal dalam membantu tugas DPS melakukan proses pemeriksaan aspek pemenuhan syariah.

\section{DAFTAR PUSTAKA}

Agoes, S. 2012. Auditing (Pemeriksaan Akuntan) Untuk Kantor Akuntan
Publik Jilid 1, Edisi Keempat. Jakarta: Salemba Empat

Antonio, M. S. (2001). Bank Syariah dari Teori ke Praktik. Jakarta: Gema Insani Press.

Baehaqi, A. 2014. Usulan Model Sistem Pengawasan Syariah pada Perbankan

Syariah di Indonesia. Jurnal Dinamika Akuntansi dan Bisnis, Vol. 1, No. 2, September 2014, Hlm. 119-133.

Chapra, M.U. dan Ahmed, H. 2002. Corporate Governancen For Islamic Financial Institution. Jeddah: IRTIIDB.

Dogarawa, Ahmad B. 2013. Hisbah and the Promotion of Ethical Business Practices, International Journal of Islamic and Middle Eastern Finance and Management, Vol. 6 Iss 1 pp. 51 63.

Eriyanto, 2011. Analisis Isi: Pengantar Metodologi untuk Penelitian IlmuKomunikasi dan Ilmu-Ilmu Sosial Lainnya. Jakarta: Kencana Prenada Media Group.

Halim, M. 2011. Eksistensi Wilayatul Hisbah dalam Sistem Pemerintahan Islam. Jurnal Ilmiah Islam Futura, Vol. X No. 2.

Haniffa, R. 2010. Auditing Islamic Financial Institutions. Islamic Finance: Instruments and Market. Qfinance.

Imran, M. S., Ahmad, A., Bhuiyan, Md. Z. H. 2012. Auditing in Islamic Perspective and Auditing as Practiced in some selected Islamic Banks Operating in Bangladesh. IIUC Studies.

ISRA. 2015. Sistem Keuangan Islam: Prinsip dan Operasi. Jakarta: Rajawali Pers.

Kamayanti, A. 2016. Metode Penelitian Kualitatif Akuntansi: Pengantar Religiositas Keilmuan. Malang: Yayasan Rumah Peneleh (Seri Media $\&$ 
Kasim, N., Hameed, S., \& Sulaiman, M. Shariah Auditing in Islamic Financial Institutions: Exploring the Gap Between the "Desired" and the "Actual", Global Economy \& FinanceJournal Vol. 2 No. 2 September 2009. Pp. 127-137.

Khan, M. A. 2016. Institusi Hisbah Dalam Ekonomi Islam, dalam buku Hisbah, Institusi Pengawasan Publik (ed terjemah). Hisbah Center for Reform.

Lahsasna, A., Hameed, S., dan Alhabshi, S. O. tt. Shariah Audit: Evidence \& Methodology in Islamic Finance. INCEIF Centre for Islamic Wealth Management (CIWM).

Mardiyah, Q. dan Mardian, S., 2015, Praktik Audit Syariah Di Lembaga Keuangan Syariah Indonesia. Akuntabilitas: Vol. VIII No. 1, April 2015.

Mohiuddin, G. M. 2012. Auditing: Conventional and Divine Perspective. Research Journal of Finance and Accounting.

Rini \& Fitri, Y. 2015. The Effect of Audit Communitte Role and Internal Control Effectiveness at Islamic Bank Indnesia. The Journal of Tauhidinomics Vol. 1 No. 1 (2015): 81-92.

Thoyibatun, S. 2009. Struktur Pengendalian Intern Bank Perkreditan Rakyat Syariah dan Konvensional. Jurnal Ekonomi Bisnis, Tahun 14, Nomor 3.

Uddin, Md. Helal., Ullah, Md. Hafij. and Hossain, Md. Musharof., 2013, An Overview on the Basics of Islamic Audit. European Journal of Business and Management Vol.5, No.28.

Yaacob, H. 2012. Issues and Challenges of Shari'ah Audit in Islamic Financial Institutions: a Contemporary View. 3rd International Conference on Business and Economics Research, Bandung, Indonesia.

Yaacob, H. and Donglah, N. K. 2012. Shari'ah audit in Islamic financial institutions: The postgraduates perspective. International Journal of Economic and Finance. 